\title{
Doing feminist collaborative event ethnography
}

\author{
Laura Zanotti ${ }^{1}$ \\ Kimberly R. Marion Suiseeya \\ Purdue University, USA \\ Northwestern University, USA
}

\begin{abstract}
Feminist political ecologists have transformed mainstream political ecology since its inception. The foundational and current work of feminist political ecologists indicate that their field is attentive to the epistemological foundations of power, inequities, and inequalities that cut across intersectional identities and hierarchies of difference and at the sites of environmental conflict and governance. Feminist political ecologists have made important theoretical interventions in the interdisciplinary community of political ecologists, but the use of feminist methodologies and 'team-based environmental science' can be expanded. We argue that revisiting feminist methodological commitments is critical for furthering how feminist political ecology examines how, and in what way, power and privilege operate in the contexts where environmental knowledge is produced. We make our argument by drawing upon a multi-year, multi-sited project to describe how collaborative event ethnography (CEE) offers many possibilities to reassess feminist political ecology research designs. We show how the recognition of diverse and plural epistemologies are foundational preconditions to integrating feminist principles in feminist political ecology research. We find that integrating reflexivity, responsibility, and co-production in research designs create opportunities for, and challenges to, carrying out feminist political ecological practice. In so doing, the integration of feminist methodologies are critical to disrupting knowledge hegemonies and providing new modes of practicing feminist political ecologies.
\end{abstract}

Keywords: Collaborative event ethnography, feminist political ecology, feminist methodologies, global environmental governance

\section{Résumé}

Les écologistes politiques féministes ont transformé l'écologie politique dominante depuis sa création. Les travaux fondamentaux et actuels des écologistes politiques féministes indiquent que leur domaine est attentif aux fondements épistémologiques du pouvoir, des inégalités et des inégalités qui traversent les identités

\footnotetext{
${ }^{1}$ Dr. Laura Zanotti, Associate Professor, Department of Anthropology, Purdue University, West Lafayette, Indiana 47907, USA. Email: lzanotti "at" purdue.edu. Dr. Kimberly Marion Suiseeya, Assistant Professor, Department of Political Science, Northwestern University, USA. Email: kimberly.suiseeya "at" northwestern.edu. Acknowledgements: This research was supported by Purdue Climate Change Research Center, Purdue University's Center for the Environment, the Department of Political Science at Purdue University, Purdue University's College of Liberal Arts, the R. Barry Farrell Fellowship in the Department of Political Science at Northwestern University, and the Center for Native American and Indigenous Research at Northwestern University. CEE relies on collaboration, in coordinating fieldwork, collecting and analyzing data, and thinking through meaning, and this paper reflects the efforts of the larger team working on site in Paris. The Paris-COP21 CEE team is: Kimberly R. Marion Suiseeya, Laura Zanotti, Scott Benzing, Sarah Huang, Fernando Tormos, Suraya Williams, and Elizabeth Wulbrecht. The 2016 WCC CEE team is: Kimberly R. Marion Suiseeya, Laura Zanotti, Sarah Huang, Kate Haapala, Savannah Schulze, Kate Yeater and Elizabeth Wulbrecht. We would like to thank our colleagues, Indigenous leaders, scholars and referees who gave us critical input throughout the writing of this article. Our institutions are on or near the homelands as well as served as a site of healing, trade, and travel for the Peoples of the Council of Three Fires (the Ojibwe, Potawatomi, and Odawa), Menominee, Miami, Ho-Chunk, Peoria, Kaskaskia, Peankashaw, Wea, Mascoutin, Sauk, Mesquaki, Kickapoo, and Chickasaw Nations. We also recognize Northwestern University's historical relationship with the Cheyenne and Arapaho. These lands continue to carry the stories of these Nations, their forced removal, and their struggles for survival and recognition. As scholars, we have a responsibility to acknowledge both the Peoples as well as the histories of dispossession that have allowed for the growth of these institutions. By reflecting on these histories, we hope to actively address the role that our universities have played in shaping them. This is Purdue Climate Change Research Center - PCCRC paper number \#2004.
} 
intersectionnelles et les hiérarchies de la différence et sur les sites de conflits environnementaux et de gouvernance. Les écologistes politiques féministes ont fait d'importantes interventions théoriques dans la communauté interdisciplinaire des écologistes politiques, mais l'utilisation des méthodologies féministes et de la «science de l'environnement en équipe» peut être étendue. Nous soutenons qu'il est essentiel de revoir les engagements méthodologiques féministes pour approfondir la manière dont l'écologie politique féministe examine comment et de quelle manière le pouvoir et les privilèges opèrent dans les contextes où les connaissances environnementales sont produites. Nous avançons notre argument en nous appuyant sur un projet pluriannuel et multi-sites pour décrire comment l'ethnographie événementielle collaborative (CEE) offre de nombreuses possibilités de réévaluer les conceptions de la recherche en écologie politique féministe. Nous montrons comment la reconnaissance d'épistémologies diverses et plurielles est une condition préalable fondamentale à l'intégration des principes féministes dans la recherche en écologie politique féministe. Nous constatons que l'intégration de la réflexivité, de la responsabilité et de la coproduction dans les modèles de recherche crée des opportunités et des défis pour la mise en œuvre de la pratique de l'écologie politique féministe. Ce faisant, l'intégration des méthodologies féministes est essentielle pour perturber les hégémonies de la connaissance et fournir de nouveaux modes de pratique des écologies politiques féministes.

Mots-clés: Ethnographie collaborative d'événements, écologie politique féministe, méthodologies féministes, gouvernance environnementale mondiale

\section{Resumen}

Las ecologistas políticas feministas han ido transformando la ecología política dominante desde su inicio. Tanto los trabajos que componen su fundamento como los actuales de las ecologistas políticas feministas indican que la investigación ecológica política feminista está atenta a los fundamentos epistemológicos del poder, las desigualdades y las desigualdades que atraviesan las identidades intersectoriales y las jerarquías de diferencia y exclusión, y llaman la atención sobre la autoridad en los sitios de protección ambiental. conflicto y gobernanza. Si bien las ecologistas políticas feministas han realizado importantes intervenciones teóricas dentro de la comunidad ecológica política interdisciplinaria, todavía queda mucho trabajo por hacer para responder al trabajo establecido en las metodologías feministas y las tendencias recientes en la ciencia ambiental basada en el equipo. Argumentamos que revisar los compromisos metodológicos feministas es fundamental para promover cómo la ecología política feminista examina cómo y de qué manera funcionan el poder y los privilegios en los contextos en los que se produce el conocimiento ambiental en entornos de equipo. Hacemos nuestro argumento recurriendo a un proyecto de varios años y múltiples ubicaciones para describir cómo la etnografía de eventos de colaboración (CEE) ofrece muchas posibilidades para reevaluar los diseños de investigación de ecología política feminista. Mostramos cómo el reconocimiento de epistemologías diversas y plurales son precondiciones fundamentales para integrar los principios feministas en la investigación de la ecología política feminista. Descubrimos que la integración de la reflexividad, la responsabilidad y la coproducción en los diseños de investigación crea oportunidades y desafíos para llevar a cabo la práctica ecológica política feminista. Al hacerlo, la integración de las metodologías feministas es fundamental para interrumpir las hegemonías del conocimiento y proporcionar nuevos modos de practicar las ecologías políticas feministas.

Palabras claves: Evento colaborativo etnografía, ecología política feminista, metodologías feministas, gobernanza ambiental global

\section{Introduction}

Since the 1990s, feminist political ecologists have transformed mainstream political ecology approaches by applying gendered and intersectionality analyses to political economic, ecological, and discursive formations of asymmetrical power relationships at sites of environmental conflict and governance (Elmhirst 2011; Hawkins et al. 2011; Mollett and Faria 2013; Rodó-de-Zárate and Baylina 2018). While feminist political ecologists (FPE) have made important theoretical interventions within the interdisciplinary community of political ecology (PE), there is still much work to be done to respond to use of feminist methodologies and 'team-based environmental science' approaches (Alcoff and Potter 1993; Bordo and Jagger 1989; Corson, Campbell and MacDonald 2014; Jarzabkowski, Bednarek and Cabantous 2015; Leavy and Harris 2018; Shayne 2014). For example, feminist methodologies have long politicized the research process, and in doing so their proponents have advocated for generating a transformative praxis that entails integrating specific epistemological 
commitments within research designs, such as attentiveness to reflexivity, representation, embodiment, and social action (Caretta and Riaño 2016; Hesse-Biber 2011; Margaret Fonow and Cook 2005; Sultana 2020). Moreover, recent calls in the environmental sciences to adopt collaborative, participatory, decolonial, and action team-based research are reflective of moments where researchers show commitment to recognizing how power imbalances imbue research processes, and where more equitable relationships during and across research life cycles may be cultivated (Gray et al. 2020; Zanotti et al. 2019; Sultana 2020). These new research approaches often necessitate team-based methodologies. To this end, we argue that revisiting feminist methodological commitments is critical for furthering how feminist political ecology examines how and in what way power and privilege operate in the contexts in which environmental knowledge is produced in team-based settings. Particularly, we are interested how feminist political ecologists can carry out the core commitments of feminist methodologies in their research in order to examine the multiple, often subtle, ways in which power flows through environmental work.

We make our argument by drawing upon a multi-year, multi-sited collaborative event ethnography (CEE) project to describe how we developed a way to integrate feminist methodologies into feminist political ecology research. Collaborative event ethnography, an approach to qualitative research at mega-events, emerged as a unique team-based approach to respond to the growing significance of sites of global environmental governance (Campbell et al. 2014; Corson, Campbell and MacDonald 2014). Conceptualizing mega-events as ethnographic field sites is a primary innovation and contribution advanced by the early pioneers of CEE, who defined how a team of researchers could conduct ethnography at the same event in real-time (Campbell et al. 2014). To this end, the CEE method considers sites of global environmental governance not as singular, but as events which are "critical historical junctures", "bundles of social relationships and power dynamics", and "provid[e] the institutional context to ... become field-configuring events" (Corson, Campbell and MacDonald 2014: 28-29). Our adoption of CEE and application of feminist methodologies to its practice contributes to the growing body of literature in different fields on how and in what way to best carry out interdisciplinary team-based ethnography.

The overall goal of the CEE research featured in this piece was to design and implement a feminist political ecological project that investigates how Indigenous Peoples and Local Communities access, engage, and influence sites of global environmental governance. We explicitly employed a feminist, team-based, qualitative, interdisciplinary research design by engaging in three types of ethnography: collaborative event, visual, and digital ethnography. We integrated an emphasis on attending to power dynamics across all phases in the research design, particularly around the feminist principles of reflexivity, responsibility, and coproduction. In our investigation, we were interested in refining CEE to better harness feminist methodologies in a feminist political ecology approach. In attending to these questions, we suggest that CEE can contribute to social science approaches to power in its adoption of feminist methodologies. Moreover, as a team of nonIndigenous researchers we were especially attentive to settler-scholar components and engaged research possibilities of team-based science (Hall et al. 2008: 3; see also Bozhkov et al. 2020).

In the pages that follow, we highlight the challenges and strengths that came with building a feminist political ecology CEE team and how attention to power in our methodological strategy was critical for cultivating a team-based ethnographic research design. To do so, first we chart why a renewal of feminist methodologies in feminist political ecological work are critical and relevant for team-based environmental social science. Second, we detail the decision-making that drove our research design as a response to integrating feminist approaches in our work. Third, we discuss the tensions and synergies of adopting feminist methodologies in team-based feminist political ecology work, i.e. the effects of the practice. In doing so, we illuminate the methodological as well as the epistemological considerations of different team-based research strategies in the context of ethnographically-focused feminist political ecology. We show how reflexivity, responsibility, and co-production interact to create opportunities for and challenges to carrying out feminist political ecological practice. In other articles, we detail our empirical findings from this research (see Marion Suiseeya and Zanotti 2019). As the goal of this article is to advance feminist methodological considerations in team-based ethnographic work, we place a sharp focus on how the research design was formulated to respond to concerns about power relationships within and across the team and its ethnographic practice. 


\section{Renewing feminist methodologies: new pathways for feminist political ecology}

Since its formalization in the early 1990s, political ecology has become a research framework and a community of practice, one that explores the ideational and material consequences, and formations, of asymmetrical power relationships in multi-scalar contexts in which environmental issues, access, use and impacts are played out (Robbins 2012). Feminist political ecology has sought to consistently challenge and expand political ecology by amplifying feminist theories (Elmhirst 2011; Rocheleau 1995; Sultana 2020). We started our work from the premise that FPE has much to offer team-based environmental science, but that methodological innovation and change was required to fully realize a feminist team-based research design.

Feminist political ecologists have continued to push for radical and critical approaches in political ecology. For example, they have integrated feminist science studies, feminist postcolonial studies, feminist standpoint and intersectionality theories in PE, as well as refined substantive questions and foci on different and perhaps less visible forms and dynamics of power (Elmhirst 2011; Rocheleau et al. 1996). As a result, researchers have established a shared framework for doing feminist political ecology, prioritizing intersectional approaches to the following political ecology research streams:

1) emphasizing the relevance of examining inter- and intrapersonal scales of analyses in addition to recognizing the interplay between and among different scales;

2) examining substantive aspects of socio-environmental change, including how gender intersects with environmental degradation and conservation;

3) analyzing the distributional, processual, and recognitional effects on, and the agency of, Indigenous Peoples and Local Communities, such as engaging with questions about dispossession, displacement, use and access to natural resources; and

4) exploring epistemic norms and equity concerns, such as the neoliberalization of nature and enactments of good governance or the best available science. (see Hawkins et al. 2011; Mollett and Faria 2013; Todd 2016)

While feminist political ecologists originally sought to grow political ecology by promoting a gendered approach, subsequently they have expanded these efforts to improve the broader theoretical contributions made by political ecology. Ahlborg and Nightingale (2018: 385), for example, note that political ecologists have benefited from engagement with feminist theorists to "advance[e] a relational understanding of power and unsettling the idea that power is a resource that can be held by individuals." Mollet and Faria (2013: 116) suggest that feminist political ecologists have made important strides in "acknowledge[ing] ... the role of spatial and embodied practices in constituting gendered subjectivity", although they also argue that much work still needs to be done to explore gender and race. Other feminist political ecologists have reinforced the importance of intersectionality and the interworkings of subjectivity and embodiment in environmental conflict and change (Elmhirst 2011; Mehta 2016; Nightingale 2011). Elmhirst (2011: 131) highlights how a focus on bodies and households is an important scale of investigation; she cautions that scholars should "recogni[ze] that it is frequently at the level of the intimate that national and international power relations are produced and sustained." The foundational works of feminist political ecologists and their ongoing dialogues indicate that FPE inquiry is attentive to the epistemological foundations of power, inequities, and inequalities that cut across intersectional identities and hierarchies of difference and exclusion, and FPE draws attention to authority at sites of environmental conflict and governance. In this way, feminist political ecology work now draws attention to discursive and institutional forms of power, historical legacies of injustice, and structural conditions of violence to make visible pathways for emancipatory politics (See Table 1). 


\begin{tabular}{|c|c|c|}
\hline Phases & Approaches & Political Ecology implications \\
\hline First Phase & $\begin{array}{l}\text { Gendered dimensions of } \\
\text { environmental change - role based } \\
\text { and relational feminist objectives, } \\
\text { strategies and practices } \\
\text { Corollaries - Environmental } \\
\text { Justice and Ecofeminism } \\
\end{array}$ & $\begin{array}{l}\text { Scales - household and other physical and spatial } \\
\text { relations } \\
\text { Power - gendered relations, rights, and grassroots } \\
\text { activism including multiple actors and their relations } \\
\text { and values at stake } \\
\text { Knowledge - gendered environmental knowledges }\end{array}$ \\
\hline Second Phase & $\begin{array}{l}\text { Post-structuralism and } \\
\text { performative approaches }\end{array}$ & $\begin{array}{c}\text { Scales - interconnections, embodiment, multiple and } \\
\text { plural } \\
\text { Power - gendered discourses, decentered subject } \\
\text { Knowledge -intersectionality, intersections and } \\
\text { fragmentations of subjectivities, ideologies, and } \\
\text { identities, emotional dimensions } \\
\end{array}$ \\
\hline Third Phase & $\begin{array}{l}\text { Intersectional, postconstructivist, } \\
\text { anti-colonial, queer ecologies and } \\
\text { Indigenous feminisms }\end{array}$ & $\begin{array}{c}\text { Scales - nonlinear and plural temporalities and } \\
\text { geographies } \\
\text { Power - Knowledge - settler colonial knowledge } \\
\text { production, co-production, Indigenous knowledge } \\
\text { systems }\end{array}$ \\
\hline
\end{tabular}

Table 1: Phases of Feminist Political Ecology. Adapted from Elmhirst (2011)

There has been some methodological innovation within political ecology and in the environmental social sciences on how to deal with power dynamics in research (Dhillon 2018; Hall et al. 2008; Mautlis and Moyer 2017; West 2018). Geographers, anthropologists, and scholars in other disciplines have called for more attention to power in the researcher-researched relationship, as well as the circulation of their work and its relevance to the peoples with whom they work. This has been especially been so within Indigenous and decolonizing research frameworks (Harrison 1991; Lassiter 2005; Thomas 2018; Tuhiwai Smith 2013). Community-engaged research, multispecies research, participatory action research and mapping, and citizen science are some of the methodologies that seek to establish new research design norms in order to co-produce critical, relevant and useable knowledge to address socio-environmental changes (see Lamb 2018; Nyantakyi-Frimpong 2019; Velasquez-Runk 2014). For feminist political ecology, methodological recommendations emerged as early as 1995 with Rocheleau's oft-cited piece Maps, numbers, text, and context: mixing methods in feminist political ecology (Rocheleau 1995) and recent work has highlighted a commitment to praxis (Harcourt and Nelson 2015; Sultana 2020). There is also some scholarship on the interrelationships of knowledge and action in geography and anthropology; this is often focused on the ethics of working with research participants or public-facing and engagement activities (e.g. see Jarosz 2004). While these are highly relevant and critical, they do not always address power within the academy explicitly, or power within and across research teams (Sundberg 2003).

Feminist methodologies and praxis writ large seek to directly address power imbalances not only in the substantive aspects of research but in all phases of knowledge production (Jagger 2008). Earlier feminist work has established the Eurocentric and patriarchal foundations of scientific knowledge and its normative dimensions in mainstream research practice (Haraway 1988). Research can too easily emphasize certain social relations, labors, positionalities, and sources of knowledge over others, creating epistemic inequalities, exclusion, and sites of privilege (Caretta and Riaño 2016). Feminist scholars have called attention to the conditions, forms, and modes of knowledge production in the research process, from conceptualization to analysis and write-up (Caretta and Riaño 2016: 258-259; Jaggar 2008; Jasanoff 1996). This entails examining "situated knowledges" as well as the power relations that are inevitably a part of the process of knowledge production, including who is considered a knowledge holder, and the dynamics of social relations and labor within the research team (Haraway 1988; Harding 1991; see also Corson, Campbell and MacDonald 2014: 29). 
In our call to revisit integrating feminist methodologies in team-based FPE, we suggest that feminist political ecologists should continue to recognize epistemic and ontological norms of knowledge production within research teams and in their home institutional contexts - this is also a central concern for decolonizing methodologies (Dhillon 2020; Todd 2016; Tuhiwai Smith 2013). FPE can demonstrate the integration of insights from feminist scholars in studies of power (Ahlborg and Nightingale 2018: 383; Nightingale and Rankin 2014; Rocheleau 2008).

In sum, most of the advances in feminist political ecology in recent years have focused on the theoretical aspects of research, and not always on transformations in the methodologies in which the work is carried out, especially in a team-based environment. The groundbreaking work that feminist political ecologists conducted to advance the substantive, empirical, and conceptual aspects of political ecological research is much more prominent than new feminist-based methodologies, although there are some exceptions, especially relating to the management of and collaboration among researchers on teams (Mehta 2016; Mollett and Faria 2018; Rocheleau 1995; Sultana 2020). As such, we suggest that feminist approaches still have much to contribute to feminist political ecology frameworks in order to address the power dynamics within team-based environmental research, especially within research teams who also seek to substantively address these dynamics: in our case, at sites of environmental change, conflict or governance.

Moreover, we acknowledge that the growth of team-based, inter- and transdisciplinary practice in the environmental sciences, which poses new challenges and considerations, provides an important moment to renew and revisit feminist commitments to doing feminist political ecology. Our CEE team is a representative example of the rise in team-based environmental social sciences. Both CEE and team-based ethnography are still relatively new within and across political ecology and its associated fields, so there is much room for innovation and change at this time. In the sections that follow, we draw from our CEE project to discuss applying feminist methodologies to team-based feminist political ecological projects. In response to emerging trends in political ecological methodologies and relying on established norms in feminist research, we discuss areas of the research design that require attention to further integrate our empirical explorations of power within team designs. We then highlight how reflexivity (especially emotional labor), responsibility, and co-production were important sites of contestation in our work, which we see as fertile areas for disrupting customary research designs and academic norms.

\section{Sites of global environmental governance}

This research, which took place at the twenty-first Conference of Parties of the United Nations Framework Convention on Climate Change (UNFCCC COP21, hereafter COP21) and the 2016 World Conservation Congress (WCC), investigated how Indigenous Peoples and Local Communities access, engage, and influence global environmental governance. Starting in the 1960s, meetings like COP21 and WCC have become normative spaces to debate and make decisions about global environmental governance, structuring discourses and creating policies that have high impact in communities around the globe. Global environmental governance sites are comprised of complex and expansive networks of actors with multiplicities of identities, ranging from nation-states, to non-governmental organizations (NGOs), industry partners, and other invested stakeholders (Brosius and Campbell 2010; MacDonald 2010; Massé et al. 2020; O'Neill 2017). The UNFCCC meetings, the World Conservation Congress, the World Parks Congress, and the Convention of Biological Diversity are just a few examples of sites of global environmental governance that meet regularly to debate and determine environmental goals and outcomes.

Indigenous Peoples and Local Communities have regularly engaged these sites in their broader pursuits of rights and recognition because of the direct impacts these meetings have on their wellbeing and livelihoods. Theoretically, we were interested in engaging sites like WCC and COP21 to help us understand how the influence of Indigenous Peoples and Local Communities unfolds in state-dominated, multi-actor spaces. While each site facilitates Indigenous Peoples and Local Communities attendance and Indigenous participation has increased at both sites, there is variation across them, in the extent of participation and engagement during negotiations, and how this is facilitated. There are formal rules for participation, including accreditation, official group status, procedural rules of engagement, and the number of entry points for participation (e.g. side events, 
pavilions, working groups, contact groups, committees, etc.), and norms that govern the forms and use of knowledge. There is also variation in the selection of topics and issues for discussion.

Understanding how Indigenous Peoples and Local Communities access, engage, and pursue their participation at these events is important for capturing the subtle and hidden dynamics of international politics that shape broader possibilities for governance (Bäckstrand 2006; Kuyper et al. 2017). Despite research that shows that Indigenous Peoples and Local Communities are important for promoting good global environmental governance and are amongst the groups most impacted by it (Bäckstrand 2006; Elliott 1998), there has been remarkably little attention to how Indigenous presence at sites of global environmental governance 'works' (recent exceptions include Doolittle 2010; Marion Suiseeya 2014; Reimerson 2013; Robbins 2012: 166; Wallbott 2014; Whittier et al. 2015). Instead, research illustrates that Indigenous Peoples' engagement at these global policy-making events remains constrained not only by their lack of access to traditional sources of power, but also by the rules, structures, and discursive practices of the institutions they seek to influence, ultimately limiting their ability to achieve desired policy outcomes (Wallbott 2014). How power relations are expressed, embodied, and articulated in different cultural forms, built environments, social processes, institutional structures, discursive strategies, notions of expertise, and epistemic and ontological communities, is a central question for feminist political ecologists. How various actors cultivate and translate their power into influence in international policy-making processes is a central question for scholars of international relations. Our approach combines feminist political ecology and international relations research, demanding attention to these diverse and plural forms of power and team-based methodology.

In doing so, we adopt core assumptions regarding power and influence that draw from interdisciplinary and feminist approaches, especially as they intersect team-based approaches to environmental politics and actors who are typically considered by elites to be marginalized. Of particular interest to us was not only how power may emerge at the events, but also how it manifested in subtle ways within the team, and among participants. Specifically, we integrate feminist political ecological approaches to power, which provides a framework that directs attention to more subtle, relational forms of power, to uncover how "plural, ambiguous, and often contradictory forms of power" unfold at sites of global environmental governance (Marion Suiseeya and Zanotti 2019). This approach allows us to consider multiple dimensions and sources of power at work in real time, and opens possibilities for identifying diverse mechanisms and forms of influence.

\section{Methodology: building an interdisciplinary feminist CEE research design}

Sites of global environmental governance pose several challenges for researchers who wish to capture and understand their dynamics, especially the affective and embodied dimensions of practice. We refined the CEE methodology to reflect our adoption of feminist commitments with special attention to how visible and invisible forms of power emerge and are distributed inequitably at sites of global environmental governance, and correspondingly, how power is distributed differently within and across research teams. As noted above, feminist approaches to CEE can reveal how team members and participants experience power, capture the micro-dynamics of governance processes, and uncover how groups and Peoples who are considered least likely to have power in international politics can cultivate influence to make progress towards their broader objectives (Corson, Campbell and MacDonald 2014: 24-28; MacKay and Levin 2015). In part, this is achieved by addressing the social relations, labors, and positionalities within and across the research design (Caretta and Riaño 2016). Key concerns in our research design are summarized in Table 2.

To address epistemological and disciplinary tensions as well as those that might intersect with diverse labors, relations, and knowledge, we were committed to epistemologically interweaving Tuana's (1996: 18) principles of feminist practice in our design. Tuana (1996: 18) argues the first step in disrupting normative researcher power dynamics is to replace the traditional model of the knower as a detached, disinterested individual with the dynamic model of engaged, committed individuals in communities. The second is to recognize the epistemic value of affective processes, producing and managing emotions (Oksala 2016; see also González-Hildago and Zografos 2020). The third is to examine the role of embodiment in the knowledge process (Tuana 1996). 


\begin{tabular}{|c|c|}
\hline $\begin{array}{l}\text { Research design } \\
\text { and methodology }\end{array}$ & A Feminist Political Ecology approach \\
\hline Research question & $\begin{array}{l}\text { - Intersectional approach to examining actors, especially local communities at sites of Global } \\
\text { Environmental Governance (GEG) }\end{array}$ \\
\hline $\begin{array}{l}\text { Ontologies and } \\
\text { epistemologies }\end{array}$ & $\begin{array}{l}\text { - Adoption of Tuana's (1996) principles of practice (1) Replacing the traditional model of the knower as } \\
\text { detached, disinterested individual with the dynamic model of engaged, committed individuals in } \\
\text { communities. (2) Recognition of the epistemic value of affective processes. (3) Examine the role of } \\
\text { embodiment in the knowledge process } \\
\text { - } \quad \text { Additional emphasis on valuing knowledge co-production and collaboration } \\
\text { - Emphasis on interdisciplinary work } \\
\text { - Recognition of power and privilege and settler colonial histories of research teams and institutions } \\
\text { - } \quad \text { Atthin which we affiliate } \\
\end{array}$ \\
\hline Case selection & $\begin{array}{l}\text { - Criteria for case selection included sites that historical were influential in determining global } \\
\text { environmental governance, historically sites of engagement for Indigenous Peoples and Local } \\
\text { Communities, sites of participation and registration for Indigenous Peoples and Local Communities, } \\
\text { sites that debate and discuss policies relevant to Indigenous Peoples and Local Communities, Sites } \\
\text { which hosted formally or informally side events led by or engaged by Indigenous Peoples and Local } \\
\text { Communities, and sites that had counter-events led by or engaged by Indigenous Peoples and Local } \\
\text { Communities pre, during, or post-event. } \\
\text { - Assumption that individuals/actors expressed multiple, plural, and intersectional identities that were } \\
\text { inter- and intra-subjectively constituted } \\
\text { - Considered digital domain as a field site itself, to represent the "porous" boundaries of Global } \\
\text { Environmental Governance (GEG) as well as to capture virtual participation. }\end{array}$ \\
\hline $\begin{array}{c}\text { Team } \\
\text { composition and } \\
\text { flow }\end{array}$ & 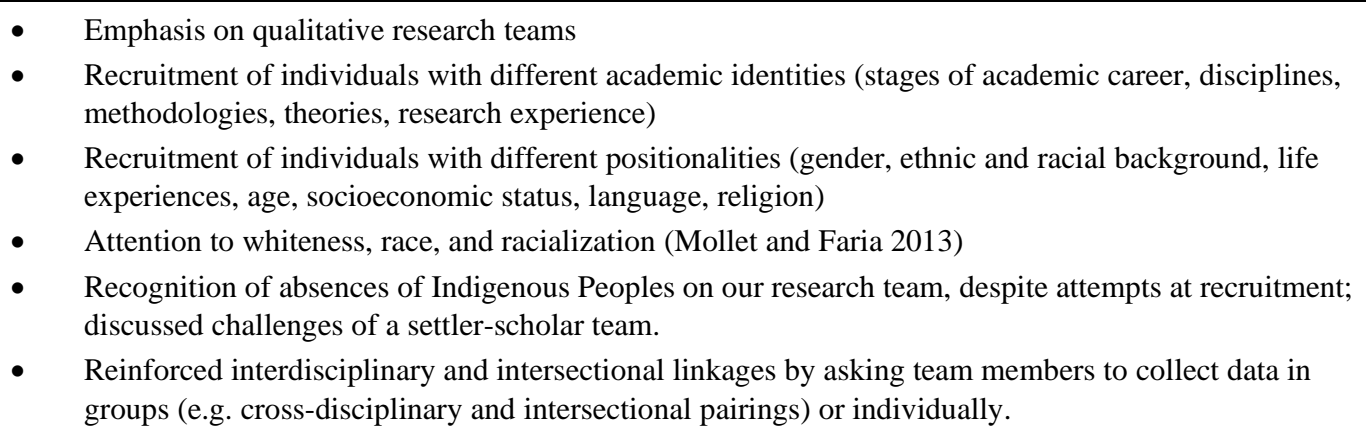 \\
\hline $\begin{array}{l}\text { Team building } \\
\text { and mentoring }\end{array}$ & $\begin{array}{l}\text { - Cascade, concurrent and peer-to-peer mentoring to make mentor "labor visible" (D'Ignazio and Klein } \\
\text { 2016: np) } \\
\text { - } \quad \text { On-site trainings mandatory for face to face interactions } \\
\text { - Team training included the following intersecting modules: (1) collaborative event ethnography; (2) } \\
\text { politics of scale, translation, and performance; (3) ethnographic methods; and (4) care and logistics. } \\
\text { - Established shared vision of team, research and goals with different team members contributing to the } \\
\text { modules and discussion }\end{array}$ \\
\hline Sampling & $\begin{array}{l}\text { - A thematic matrix and theory-driven politics for conducting CEE across events (COP21 and WCC) } \\
\text { rather than viewing each event in isolation. } \\
\text { - Same theory-driven politics of representation for team members to follow: scale, translation, and } \\
\text { performance/performativity } \\
\text { - Events based on our team-based research questions, and with attention to power dynamics }\end{array}$ \\
\hline
\end{tabular}




\begin{tabular}{|c|c|}
\hline Methods & $\begin{array}{l}\text { - Critical feminist ethnographic approach to interviews, participant observation and active participant } \\
\text { observation, visual methods, and digital methods } \\
\text { - } \quad \text { Live blogging and tweeting at event, to engage in public forms of scholarship }\end{array}$ \\
\hline Analysis & $\begin{array}{ll}\text { - } & \text { Individual and team debriefings } \\
\text { - } & \text { Collective preliminary analyses to generate an iterative coding scheme } \\
\text { - } & \text { Writing retreats } \\
\text { - } & \text { Plural analysis approaches }\end{array}$ \\
\hline $\begin{array}{c}\text { Knowledge } \\
\text { sharing }\end{array}$ & $\begin{array}{ll}\text { - } & \text { Blog posts in relevant academic and policy outputs } \\
\text { - } & \text { Conference presentations } \\
\text { - } & \text { Engagement with and feedback from Indigenous scholars and participants } \\
\text { - } & \text { Peer-reviewed publications }\end{array}$ \\
\hline
\end{tabular}

Table 2: Applying a Feminist Political Ecology approach. Source: Authors.

We suggest team-based forms of ethnography and a systematic approach to analyzing relational forms of power are particularly well-suited for such a feminist research design because of the required methodological attention to reflexivity, responsibility, and co-production. In adopting this approach, we developed team-based methods at COP21 and WCC that merged more customary approaches to CEE with feminist commitments in combination with visual and digital ethnography. We engaged in "active participant observation" where team members took on a "social role that is recognizable by the community" in the different events to note access to the spaces of negotiation, relational, discursive, material, and institutional manifestations of power in representation of particular actors at the site, and historical legacies that might shape the underlying conditions of engagement (Johnson et al. 2006: 132; Sundberg 2003). We established relationships and conducted interviews to learn from Indigenous Peoples, state, and other civil society participants' experiences within the governance process and to discuss relevant information about the mechanisms through which Indigenous Peoples and Local Communities access, engage, and influence sites of global environmental governance.

We also considered visual artifacts as representations of the production of knowledge and ways of knowing (Pink 2006: 35). We co-collected visual data to assist in analyzing the interworkings of power by complementing written notes with sensory-based information and visual records of slides, event spaces, and participants. We used digital ethnography techniques that integrated real-time social media and blogging, as public scholarship, to engage with and analyze how the use of social media can expand and contract spheres of influence by introducing or amplifying voices, ideas, and identities. We studied digital sites as spaces in which "cultural identities, representations, and imaginaries ... are remade, subverted, communicated, and circulated" (Coleman 2010: 488).

In addition to our incorporation of visual and digital methods and establishment of ongoing relationships with key organizations and individuals, we made two additional shifts in our projects' methodological design. First, we made a conceptual shift to consider all members of our research team and participants at the meetings as knowledge holders. Importantly, this simultaneously allowed us to establish our values recognizing Indigenous and Local Knowledges - also recognized by the United Nations Declaration of the Rights of Indigenous Peoples as critical forms of knowledge (UNDRIP; also see Tengö et al. 2017) as well as team members who might not otherwise been considered as "holding" knowledge (e.g. undergraduate researchers). Furthermore, we recognized ways of knowing often not captured or documented in non-ethnographic forms of data collection: tacit, experiential and embodied knowledge. We therefore considered co-production within and across the team, as well as with interlocutors and mutual experiences, as jointly produced - thereby displacing the authoritative role of a singular researcher (Bain and Payne 2015; Lin et al. 2007). The second shift was to move away from normative team-based science, which historically has reinforced institutional hierarchies and patriarchal forms of knowledge production, in order to practice a form of collaborative scholarship that conforms to the standards of feminist methodologies (Haraway 1988; Jaggar 2008). This shift enhanced our 
research by considering the professional, relational, and situational and culturally specific ethics of the research process, and by making practical contributions through building research collaborations that extend within and beyond the academy (Margaret Fonow and Cook 2005; Tracy 2010).

\section{Shift 1: Reconsidering knowledge holders}

One of the first steps we took to cultivate a feminist methodology that aligned with the theoretical goals of feminist political ecology was through the selection, mentorship, conceptualization and composition of our team. In order to create a research design based on feminist principles, we adopted an approach for team building and mentoring that is informed by feminist theoretical and methodological norms. This entailed designing a project where team members were trained in shared commitments to reflexivity, responsibility, and approaches to plural knowledges (see Tuana 1996). As a CEE team, we also were committed to producing collaborative scholarship. We defined collaborative scholarship as the iterative co-production of knowledge by two or more knowledge holders throughout the research process (Djenontin and Meadow 2018: 886). Since collaboration involves the deliberate negotiation of ontologies, epistemologies, intersectional positionalities, and awareness of how and in what way knowledge is produced (Marion Suiseeya and Zanotti 2019), we acknowledged our institutional biases, conducted centralized face-to-face training, implemented a mentoring plan, and - one of our innovations to CEE - prioritized real-time social media and blogging as public scholarship. As will be seen in the discussion section, collaboration in this interdisciplinary context generated new forms and practices for co-production.

Disciplinary differences in how ethnography is adopted and enacted necessitated that we include training modules on the politics of knowledge and reflexivity as it relates to researcher power and privilege for our interdisciplinary team members. We did so by drawing attention to trainings, mentorship, and cultivation of informal spaces for dialogue. We differed from previous CEE teams in that we prioritized that these trainings (1) took place face-to-face to facilitate mentorship and interdisciplinary dialogues; (2) drew attention to allyship and diverse practices of inter- and transdisciplinarity, (3) engaged three forms of ethnography (collaborative, digital, and visual), and (4) prioritized public scholarship as part of our work. We hoped that this approach would support rapport and trust building as well as make clear our attentiveness to ontological, affective and embodied dimensions of practice. This approach also attends to power dynamics within the team in its prioritization of different forms of knowing as critical and relevant to doing feminist political ecology. While there were films, podcasts and activities required prior to the trainings, attendance was mandatory for a feminist approach in order to build relationships, draw attention to situated knowledges, and address power relationships and labors within and across the team as well as with research participants.

To build the team, we actively recruited team members at different ranks as well as those from different fields. Since we considered situated knowledge as key to disrupting dominant modes of analyses, we also sought team members with different positionalities and lived experiences (Haraway 1988). Not only did we anticipate that this would offer compelling discussions, but we also considered that it would contribute to the theoretical and methodological scrutiny of normative values and practices (see Ackerly 2000: 18). We hoped the diversity in the team composition would invite critical reflection on Eurocentric knowledge production processes, offering sites of contestation through the epistemic and ontological challenges of team-based work. We also anticipated tensions around different disciplines' approaches to theory, method and ethics. This assisted with discussions of the ethnographic-theoretical dialog, or the process of how ethnographic research develops "in dialog with theory rather than being led or structured by theory" (Pink and Morgan 2013: 357).

Our team was composed of two interdisciplinary-trained faculty members, one from a political science department and one from an anthropology department, who were joined by three graduate students and two undergraduate students (COP21) and then four graduate students and one undergraduate student (WCC). Students were in different stages of their professional careers and with differing familiarity with ethnography as method and practice. In the COP21 team, three students were from political science, one from anthropology, and one from wildlife studies. The WCC team had two students from anthropology, two with overlapping membership in an interdisciplinary environmental program, two from political science, and one student with a 
shared political science and anthropology background. Two of the graduate team members from the COP21 team joined the WCC team.

However, all team members varied in their intersectional identities, and we sought to not only be attentive to settler politics but also to gender, whiteness, race, and racialization (Mollet and Faria 2013). We had two men and four women on our COP21 team; one member identified as Asian American, one as African American, and one as Puerto Rican. Three members identified as white. We had six women members on our WCC team; one member identified as Asian American. Five identified as white.

There was an absence of Indigenous researchers in our teams, despite attempts to recruit diverse team members at our home institutions where we have affiliations and connections with Indigenous studies programs, scholars, and research centers. There are multiple reasons for this, and we recognized the pitfalls, power dynamics and challenges of a settler-scholar team (Bozhkov et al. 2020). We spent months developing training materials, especially with an attention to the long-acknowledged problems of non-Indigenous researchers working alongside Indigenous Peoples and Local Communities in global environmental governance processes (Howitt and Jackson 1998; Tuhiwai Smith 2013). We drew from the literature, experiences at sites of global environmental governance, and our conversations with Indigenous leaders and scholars as well as those who worked on behalf of Indigenous Peoples and Local Communities as we developed these materials. To address the lack of Indigenous researchers on our team, we reached out to Indigenous scholars and leaders to solicit feedback and advice on our methodology and design at different phases of the research process.

To spotlight mentorship and team development, we cultivated a social sciences and feminist research lab model of mentoring that develops a sense of community and peer-to-peer support and offered ongoing trainings for our team. We developed mentoring plans with each team member to establish individual goals and objectives. We met regularly to discuss individual and team progress, issues, and goals and provided ongoing, reflexive guidance. Moreover, student team members participated in training and practicum events - including on social media, field data collection teams, and data analysis and writing teams; and also developed related research. We use cascade (top down), peer, and concurrent (multiple mentors simultaneously) mentoring to establish meaningful coherence and credibility in work, build rapport, and establish data checking between and across team members (Ensher et al. 2001; Gray et al. 2020; Packard 2003).

By building a centrally-located team, we hoped to address some of the logistical and coordination challenges in producing collaborative scholarship as well as building trust, care, and affective work needed to attend more fully to power dynamics. Specifically, our central locations attempted to overcome the challenge of "dispersed consciousness" identified by Corson, Campbell and MacDonald (2014: 31; see also Campbell et al. 2014: 12) of collaborators that can be exasperated by geographic distance, in addition to individualistic, as opposed to team-based, tendencies in the social sciences (see also Gray et al. 2020). Through planned face-toface engagements across all phases of the process, we explicitly confront epistemological and ontological tensions through our team constitution, especially related to activist scholarship, as well as affective tensions. This is largely a function of team commitments to advancing knowledge and to a shared framework of feminist political ecology, an approach used by both faculty members in their own research programs.

Thus, trainings provided the beginning of a "structured dialogue" from which to approach a "mutual understanding" about the individual, interpersonal, and processual challenges of doing feminist interdisciplinary team-based work (O'Rourke and Crowley 2013: 1939). During the trainings, team members engaged with readings and assignments, discussed logistical questions, has a dialog about individual and group research interests, talked about power, coloniality, reflexivity and care work, and learned our CEE workflow. Team training included the following modules: (1) collaborative event ethnography; (2) politics of scale, translation, and performance; (3) ethnographic methods; and (4) care and logistics. As team members had heard about or been debriefed about the project leading up to the training, the training in both cases provided a coherent and holistic overview of the team, research and goals and importantly, to the team itself.

\section{Shift 2: Collaborative scholarship}

We introduced one of our CEE innovations during the training: our engagement with digital ethnography, specifically working with social media to advance real-time scholarship. This is one of the 
principles of doing feminist work, making it more accessible. We considered social media as a "field site" (Bonilla and Rosa 2015: 4), however we also saw digital platforms as a space for public scholarship. We designed a project website and developed a twitter handle (@pres2influence) to intersect with feminist digital humanities and feminist science and technology studies that consider how digital engagement can "register responses" that are not typically recorded (D'Ignazio and Klein 2016: np). ${ }^{2}$ The challenge was to consider tweets or posts by others as well as our team as "entry points into larger and more complex worlds" (Bonilla and Rosa 2015: 7). We coordinated scheduled and spontaneous tweets and blog posts to support these objectives. During the events, team members rotated writing our public daily blog, and tweeted across the days. Collectively, we hoped these served as anchor skillsets that would orient the team's active and engaged participant observation, and providing the beginnings of key reflections on intersectional, epistemological and ontological orientations. We sought to reflect our shared but individual embodied experience of being at the events through forms of public scholarship.

We further worked to dismantle some of the epistemological and ontological barriers that can hinder collaboration, and that are necessary when paying attention to epistemic normativity and settler colonialism in a feminist or feminist Indigenous methodologies (Todd 2016). This included extended conversations about the purpose and practice of critical feminist ethnography; conceptualizations of power, authority, and influence; how our own positionalities will impact what and how we "see" and are part of ongoing legacies of powerladen researcher-researched relationships; and, as noted above, concerns about the absence of Indigenous researchers in our teams and strategies for addressing this (see Tuhiwai Smith 2013).

We also had ongoing discussions about our own commitments to research ethics, as well as generating a collective vision of what forms of collaboration and mentoring we hoped to cultivate. Combined, these efforts helped build trust among team members and developed a shared vision for experiencing and understanding sites of global environmental governance. They also provided a space to address difficult dialogues and possible tensions across the research team. For example, as we built our blogging and twitter protocol together, we considered what ethical tweets look like. Is our work feminist, activist, or advocacy-based and how do we navigate that slippage? This strengthened our team relationality, deepened our approach to CEE, and drew attention to possible fissures that might and did bubble up to these approaches.

We addressed the social relations and labors within the team head on, and provided supportive structures in place for cross-cutting mentorship to take place. As noted above, we practiced cascade and concurrent mentoring alongside peer-to-peer mentoring and exchange from the undergraduate to the graduate to the faculty level. In a further effort to generate cross-disciplinary and intersectional linkages, in our team each faculty member was paired with at least one graduate student from a different department during COP21 and during the WCC. In addition, we were also attentive to different positionalities and identities in how team members self-identified beyond their disciplinary moorings to create pairings and groups. For example, at the events, we further reinforced linkages by asking team members to work in smaller teams (e.g. cross-disciplinary and intersectional pairings) or individually. Our shared spaces were also carefully considered for team cohesion, care work, access, and workflow. In Paris, we shared a small two-bedroom apartment not far from the site where we held team debriefings. The cramped, shared living space also meant that team members traveled together to the site each day and often spontaneously ate meals together. At the WCC, we were unable to secure a collective space and instead were in a nearby hotel. Because the WCC team included a range of experiences and positionalities, from seasoned ethnographers to first-time practitioners, we were interested in CEE as a standalone ethnographic method that might inform future practice, rather as a simply as a usable method for those already familiar with ethnography.

We highlighted theoretical responsibility as key to our work, to consider not only the most visible and established politics at sites of global environmental governance but those that are less visible in the scholarly literature. All team members used the same guide for each event they attended, and individual events were prioritized based on our team-based research questions (Brosius and Campbell 2010). Our guide included questions about the following three elements of the politics of representation: translation, scale, and performance/performativity, which we used to understand the unfolding of power at sites of global

\footnotetext{
${ }^{2}$ http://www.presence2influence.org/ https://twitter.com/pres2influence
} 
environmental governance. The politics of translation refers to how different actors define problems, solutions, and their roles in solving the problem (problematization), recruiting others to join and assume certain roles in the process of translation (interessement), defining roles and convincing others to accept and take on these roles (enrolment), and speaking for other passive actors in a network (mobilization) (Callon 1984; also see Law and Singleton 2014). The politics of scale refers to how different processes of 'scaling' shape how governance ideas emerge. These scales may be intrapersonal, interpersonal, localizing, globalizing, regionalizing, or connecting scales, and include the creation of new scales and networks (Bulkeley 2005; Mollet and Faria 2013). The politics of performance brings in a symbolic approach to CEE (Brosius and Campbell 2010), but we extended this work to consider performativity where "social differences understand as emergent and produced out of everyday practices" (Nightingale 2011: 155). We sought to tie together the ways in which these analytics not only drove theoretical aspects of our work but also how they aligned with feminist team-based approaches to knowledge production across all project phases. The team training was the first step in initiating a conversation about these theoretical engagements, which then continued over the course of the CEE.

Finally, we deployed a thematic matrix and for conducting CEE across events (COP21 and WCC) rather than viewing each event in isolation (Corson et al. 2019). The matrix was created by prioritizing the following topics as they apply to intersectional identities: Indigenous rights, forests, and biodiversity. We were particularly interested in how these topics interplay with climate change. These topics were selected because they are the core issues and discourses around which Indigenous People's and Local Communities' engagement with global environmental governance is centered, and we therefore expected to be able understand their influence on the proceedings by attending events that engaged with these issues (Brosius 2004; Doolittle 2010; Witter et al. 2015).

To this end, in order to demonstrate our prioritization of reflexivity during CEE we made overt our inclusion of care work and affective labor, documented through fieldnotes, embodiment and dialogical moments. As noted above, from the onset in team trainings, we emphasized using personal diaries (e.g. not shared with other team members) in the field. Feminist political ecology research protocols meant being attentive to affective and embodied forms of practice and included check-ins, debriefing, reflexivity and analytical memos, as well as visual methodologies making "labor visible" and (D'Ignazio and Klein 2016). These methods led to discussions early on about the different epistemological underpinnings of dominant research designs in feminist political ecology, specifically focused on anthropology and international relations, and also the way in which ethnography is considered and practiced. We anticipated that these disciplinary tensions and interdisciplinary conversations would provide a fecund arena from which to collectively engage with the project's research questions and proposed practice, as well as providing tools to support the team members.

Todd (2016: 6) reminds us that critical academic work often overlooks the historical and present-day tendency of western epistemology approaches, including critical ones, to erase Indigenous laws and philosophies in their practices and discourses. She points to recognitional issues within academia, that render Indigenous philosophies as subjects of research rather than theories in their own right, and signals other problematic aspects of doing social science. She outlines the unquestioning assumptions and biases in research and how those are assembled with a focus on "culminating" events that are valorized in "rock-star" EuroWestern science, missing critical processual aspects. She notes in order to mitigate this, one step to take, "means that we must consider our own prejudices, our own biases" (Todd 2016: 19). These, as Todd notes, require us to draw attention to the regulative norms and mechanisms of the academy. In response, our own research design, embedded institutional, individual, intra- and interpersonal and intersectional reflexive discussions. We also attempted to raise awareness about the colonial histories of our home institutions in the Global North, 'owning' our privileges and settler-scholar practices, prejudices, and team dynamics. We also recognized that there were aspects of power and privilege that we could have challenged more, and in so recognizing this weakness we sought to reconsider how and in what way we did our research.

In practice our research design unfolded in dynamic ways. A typical day for the CEE teams at both COP21 and WCC began around five or six in the morning. We would rise early and usually exhausted from the long days and short nights. We would often continue conversations started the night before, meeting in smaller and larger groups. Once inside the conferences, we would attend events as our credentials as observers allowed. 
Often, we were scheduled back-to-back in both events and, like other participants, were subject to long security lines, in the case of COP21 to enter the Blue Zone or the civil society space. In between scheduled and more casual discussions with other event attendees and participants, we would hurry between events to make sure we could find locations in the vast complexes in which the conferences were taking place. Guided by our common theory-driven framework, we co-produced the following knowledge products in real time: tweets, blogs, CEE event notes and reflections, interview notes, and multimodal, sensory information from exhibit spaces and forums. Also included in our work were the daily reflexive and analytical discussions produced collectively by the team in team meetings, smaller groups, and individually (Figure 1).

\begin{tabular}{|c|c|c|c|c|c|}
\hline Team Training & Data Management & Debriefs & Communication & $\begin{array}{l}\text { Team Dinners and Personal } \\
\text { Time }\end{array}$ & Writing Retreats \\
\hline $\begin{array}{l}\text { Asynchronous and } \\
\text { synchronous team training } \\
\text { before events took place, } \\
\text { with emphasis placed on } \\
\text { face-to-face training in one } \\
\text { geographical locale. These } \\
\text { team trainings focused on } \\
\text { interdisciplinary team } \\
\text { building, methodological and } \\
\text { theoretical considerations for } \\
\text { doing CEE, and logistical and } \\
\text { practical challenges of travel. }\end{array}$ & $\begin{array}{l}\text { We formulated a shared Data } \\
\text { Management Protocol for } \\
\text { Event and Reflective } \\
\text { Fieldnotes, Individual Time } \\
\text { Log, General and Event } \\
\text { Specific Photos, Individual } \\
\text { Photo Log, Materials Log, and } \\
\text { Blogging Guidelines }\end{array}$ & $\begin{array}{l}\text { Formal scheduled debriefs } \\
\text { for teams or subteams at CEE } \\
\text { in CEE team shared space or } \\
\text { daily 'pop up' shared space. } \\
\text { These debriefs took the form } \\
\text { of descriptive, analytical, } \\
\text { synthesizing and reflexive } \\
\text { commentary. Informal and } \\
\text { opportunistic debriefs took } \\
\text { place among team members } \\
\text { and cross-disciplinary paired } \\
\text { team members across days. } \\
\text { Faculty leads also performed } \\
\text { informal individual debriefs } \\
\text { before events and formal } \\
\text { debriefs with team members } \\
\text { after each event. }\end{array}$ & $\begin{array}{l}\text { Shared GroupMe or } \\
\text { WhatsApp Group where the } \\
\text { team could stay in touch } \\
\text { during travel, during the CEE } \\
\text { experience, and post-travel. } \\
\text { At COP21 wireless service } \\
\text { prevented high activity on } \\
\text { the GroupMe, in Honolulu } \\
\text { staying in touch via electronic } \\
\text { means remained easier. }\end{array}$ & $\begin{array}{l}\text { While we shared many meals } \\
\text { across events, we had one } \\
\text { formal planned team dinner } \\
\text { at CEE events, as a 'soft stop' } \\
\text { to relax and come together } \\
\text { as a team in the middle of } \\
\text { the events unfolding. We also } \\
\text { had planned hard stops for } \\
\text { personal time and days, and } \\
\text { were flexible with schedules } \\
\text { when team members need } \\
\text { extra self-care }\end{array}$ & $\begin{array}{l}\text { Weekend long or semester- } \\
\text { long writing retreats or stop, } \\
\text { drop, and write events were } \\
\text { scheduled across teams after } \\
\text { each event took place to } \\
\text { continue to talk about, } \\
\text { process and collaboratively } \\
\text { work on written products } \\
\text { from the events. }\end{array}$ \\
\hline CEE Ethnographic Kit & Social Media + Blogging & Analytics + Matrix & CEE Event Fieldnotes & CEE Daily Reflective Notes & Interviews \\
\hline $\begin{array}{l}\text { Team members received an } \\
\text { ethnographic "kit" for CEE } \\
\text { events, which included audio } \\
\text { recorders, audio splitters, } \\
\text { power packs, cameras, extra } \\
\text { batteries, SD cards, and a } \\
\text { carrying case }\end{array}$ & $\begin{array}{l}\text { Coordinated shared } \\
\text { Facebook Page, Twitter } \\
\text { Handle, and Blogging } \\
\text { Website for "Live } \\
\text { Fieldnotes"+. Team members } \\
\text { rotated days in which they } \\
\text { took the lead on these items, } \\
\text { and were encouraged to also } \\
\text { contribute in unplanned } \\
\text { moments as well. }\end{array}$ & $\begin{array}{l}\text { Shared analytics worksheet } \\
\text { that guided CEE team } \\
\text { members in their } \\
\text { ethnographic experience. } \\
\text { This "cheat sheetet included } \\
\text { definitions, Inclusion Criteria } \\
\text { and Examples of Politics of } \\
\text { Translation, Politics of Scale, } \\
\text { and Politics of Performance. } \\
\text { We also had a shared matrix } \\
\text { that drove our event } \\
\text { selection for each site, } \\
\text { emphasizing events that } \\
\text { focused on: Indigenous } \\
\text { rights, biodiversity, forests, } \\
\text { and climate change. }\end{array}$ & $\begin{array}{l}\text { Standardized fieldnote } \\
\text { template for each formal or } \\
\text { informal event attended that } \\
\text { cued team members for } \\
\text { event reflective notes, event } \\
\text { notes, event spatial and } \\
\text { visual notes as well as } \\
\text { photographs, and basic event } \\
\text { attributes. }\end{array}$ & $\begin{array}{l}\text { Open fieldnote template for } \\
\text { each team member to writing } \\
\text { up summarizing, } \\
\text { synthesizing, analytical and } \\
\text { reflexive thoughts at the end } \\
\text { of each day. Team members } \\
\text { were encouraged to share } \\
\text { their thoughts in team } \\
\text { debriefings, however, these } \\
\text { notes were only shared } \\
\text { between the team member } \\
\text { and project Pls. }\end{array}$ & $\begin{array}{l}\text { Shared interview protocol } \\
\text { and script for formal } \\
\text { interviews with conference } \\
\text { participants. Shared } \\
\text { interview write-up protocol. }\end{array}$ \\
\hline
\end{tabular}

Figure 1: Shared ethnographic practices. Source: Authors

After the events ended, we maintained our engagement with the team-based ethnographic process in three ways: debriefings, sharing of written materials (analytical notes), and writing retreats. To add an extra layer of engagement, the faculty team members debriefed individually with other team members about their experiences on doing ethnography in a team environment, what we could improve in the future, and the challenges they faced. This was also an important support mechanism for "re-entry" for team members as they transitioned from intensive and affectively-charged work at sites of global environmental governance, back to their regular schedules. These meetings also were spaces for us to talk about our analytical insights and what we might want to pursue as part of writing projects when the more immediate public scholarship phase of the work had come to a close. The generation of a collective codebook drew from these conversations, and also facilitated expansion of our team to include members who had not joined us at the meetings but who were invested in the research program. To this end, the team expanded and contracted during subsequent group writing retreats, depending on availability of team members; we maintained coherence and consistency with the shared commitments and orientations that all team members went through. To advance project objectives, we focused on policy/community audiences through non-traditional forms of outreach. This included crafting diverse kinds of outputs, such as policy briefs, blogs, presentations, and workshops. We aimed to disseminate these outputs through diverse media, such as social media, community networks, websites, policy and research institutes, and publicly available publications and venues. Thus, writing retreats were important sites where the team revisited their experiences and questions of power, identified and talked about futures, and began to work collaboratively on different projects. 


\section{Doing feminist collaborative event ethnography}

Over the course of COP21 we attended over 165 events, and for the WCC we attended over 104 events, which included the negotiations, side events, award ceremonies, tribunals, press releases, and permitted and spontaneous protests. In Paris, we took photos of the Adbusters campaigns and the photography series that populated the city during COP21. At the WCC, we became familiar with what we saw as problematic brightly colored photographs of the exhibit spaces in the convention center, representing different resources and peoples across the world. Jointly, we collected over 10,000 photos and twenty kilos of materials, flyers, postcards, position papers, pamphlets, recipes, and other information presented by speakers, NGOs, interest groups, and others in the area. At the WCC we were eager to sit on the final discussions as the Hawai'i commitments ${ }^{3}$ were being drafted. We became familiar with: the anti-REDD+ postcards of the Indigenous Environmental Network, the Kahuale United Nations Development Programme Equator room, the welcoming space of the Indigenous Peoples Pavilion, and the frustrations, tears, and songs that were shared with us and that we shared as the events unfolded. Indigenous Peoples and Local Communities sought agendas that upheld a rights-based approach to climate change and conservation, while also desiring transformative justice in these spaces (see Marion Suiseeya and Zanotti 2019).

Despite our attempts at interweaving Tuana's principles of practice in the selection, mentorship, and ultimate composition and conceptualization of our team as well as in our methodological practice, we faced several challenges in doing feminist team-based ethnography. The first site of tension that emerged was the heightened emphasis on reflexivity as it intersected with laying bare social relations, labors, and positionalities within and across the team. This made visible individual, researcher-to-researcher, and researcher and participant emotional labor, especially as team members participated in or witnessed the doing of the work of global environmental governance differently based on their intersectional identities. The second was embedded in the process of co-production and collaboration. Different experiences were pronounced, based on varied positionalities combined with the heightened accountability our team felt to one another and to participants. Relatedly, although the holistic and iterative life cycle of critical ethnographic research was emphasized throughout the trainings and events, many team members saw the moment of knowledge co-production as relevant only during the "data collection" phase, rather than across the entire life cycle of the research process, including all the team activities before and after events took place. These challenges, detailed further below, point to areas to improve upon in feminist team-based research designs which seek to address the interworking of how power within teams impact the study of power.

\section{Challenge I: Reflexivity}

One important innovation of our feminist CEE team was to engage explicitly with iterative and teambased reflexivity, especially around questions of power (Tuana 1996; See also Ackerly 2000). During this work, we quickly realized the ways in which interpersonal and individual reflexivity can be engaged, discussed, and stressed - especially in short-term, high-stakes field sites - was both generative but disruptive. Specifically, some of the most pronounced struggles that team members grappled with were: how and in what ways they experience emotional labor for themselves and others, their sense of accountability to the team or participants, and engagement in practices for their well-being and acknowledgement of power-laden relationships. This was especially difficult for first-time ethnographers, but all team members experienced these affect-laden waves of practice (See also Ortner 2005: 45). These generative possibilities as well as tensions emerged within (1) individual researcher practice, (2) researcher-to-researcher interactions, and (3) researcher-participant interactions.

The individual emotional labor required to maintain perceived and real expectations to the team emerged as a generative site where reflexivity and practice were managed. Team members reported key challenges were their high accountability (expectations of team/self with others) combined with balancing team and individual

3 https://www.hawaiiconservation.org/wp-content/uploads/Hawaii-WCC-Resolutions-Recommendations-OfficialVersions.pdf 
needs. As team members experienced the "bodily memory of fieldwork" (Mauthner and Doucet 2008) and sought to process it, they reported a range of feelings from a sense of deep connectedness, to uncertainty and frustration. At the same time, team members consistently highlighted that the most rewarding and challenging aspect of CEE was how emotionally, physically, and intellectually satisfying and fatiguing the experience was for them. For example, one graduate team member emphasized the individual benefits of doing this type of affect-laden work together:

Yet what is unique, and I would argue a great benefit of using this methodology, is that the individual practitioner is always connected to the team. In other words, emotions, data, and the event at large are not experienced or interpreted singlehandedly. Rather, the team as a whole is experiencing similar, albeit different, phenomena ... which provides an outlet to process through these happenings. It is my opinion that it allows for a deeper understanding of your positionality as a researcher as well as a richer engagement with the data. (WCC team member)

Others talked about initial uncertainty of team-based work that was later outweighed by the results:

I had some initial apprehension about navigating the team dynamics and of being thrown together with research team members I previously did not know. However, we built up relationships and learned about one another through living together, eating together, collecting data, conducting research, and during our free time... While each researcher had their own interests and prior knowledge and experiences to bring to the team, all team members were also very committed to the team and its priorities. (Undergraduate student, COP21 team member)

As a strength, embodied ways of knowing provide greater depth and a different way of learning what is occurring. Within CEE, it is more of a strength because of the experiential learning that comes within working on a team. This definitely has its challenges depending on the team dynamics, but I feel that CEE encourages reflexivity and an understanding of what that reflexivity brings. (Graduate student, COP21 team member)

The demand for constant reflexivity and engagement with epistemological and ontological assumptions were ongoing, and required team members to question themselves and others. However, in this case, our feminist team design seemed at least to ameliorate some of these tensions, through our priority on forging a 'relational team', thereby reconfiguring the burdens of doing team-based work and making emotional labor visible in the process.

While these intra- and interpersonal dynamics were taking place within our team, these relationships were inevitably impacted by our work with participants at the WCC and COP21. There were several examples that demonstrated how the cumulative effect of attending events made visible institutional and discursive power at sites of global environmental governance, and how different organizations and individuals perpetuated and confronted these politics of translation and performativity. This include the emotional labor of doing the work of global environmental governance by conforming to normative scripts, disrupting the discourse of negotiations, creating or expanding informal networks, and shifting the meaning and nature of ideas and identities in global governance (Witter et al. 2015). As our team members took on the role of participants and were focused on the interlocking aspects of these power dynamics, they were able to report on and experience these in real-time.

In one instance, after attending several events focused on gender and the environment at the WCC, one of our team members expressed frustration at the gender mainstreaming at the event and how these discursive strategies perpetuated the silencing of women, especially women of color. In many events, she noted, gender seemed to conform to normative scripts, despite concerted attempts to shift gendered approaches in conservation beyond universalizing discourses that did not treat all women or experiences similarly. This same 
team member also drew attention to what she saw as additional labor required by organizations and individuals to put on events which did not conform to the dominant politics of translation. Other events, which prioritized individual storytelling from women on the frontlines of climate change, disrupted the normative scripts that seemed to ultimately position women as targets of conservation or 'empowerment.'

For example, one WCC Knowledge Café event focused on the practical integration of women in natural resource management. It seemed especially problematic to this team member. This outcome was especially surprising as Knowledge Café events were a forum at the WCC that sought to explore and analyze issues related to pressing conservation issues in two-hour hosted roundtable formats. The event in question, led by large international environmental non-governmental organizations, had several concerning facets. The event was hosted by a white male conversation leader who did not seem to be a feminist ally, although did promote working with women. Seven white women and four women of color were participants in the roundtable but none were in the conversation-leader position. The topical emphasis in the discussion centered on reporting the results of systemic literature reviews. They reinforced normative notions of gender and conservation. Moreover, in the roundtable discussion the conversation leader treated women a homogenous group, promoted universalizing discourses about human rights, and suggested that conservation organizations should focus on the "most efficient" way to integrate women into organizational structures. He did not consider, and actively dismissed, the intersectional identities of women, gendered dynamics within and across communities, and the unintended consequences of integrating women into organizational structures without understanding local institutions, norms, and rules.

In debriefings and reflections, the same team member recognized what she perceived to be the additional labor and modes of knowing that a gendered-focused organization enacted to dismantle the dominant modes of presenting these same topics. In highlighting the social relations, labors, and positionalities of individual participants and organizational responses (including the team members' own), she underlined how certain organizations promoted or disrupted the discourse of conservation and natural resource management. In this case, our ethnographically-oriented approach, attuned to the embodied and emotional experiences of these events, could capture the institutional and discursive constraints that participants might face as they encounter these different dominant forces at the conference.

In contrast, activities sponsored by a gendered-focused organization at the WCC disrupted the normative scripts evident in other events, and highlighted otherwise unrecognized scales and inequalities associated with environmental change. The organization achieved this by putting on events that discussed the historical and present-day violence enacted against Indigenous women and, more importantly, how Indigenous women are at the front lines of the fight against environmental destruction and environmental change through their activism, care-work and stewardship of communities, languages, and biocultural diversity. Through these events, the fact that Indigenous women are placing their bodies in danger to protect their communities, sacred sites, and landscapes which sustain them was emphasized as a way to highlight often invisible "conservation" actors. These events prioritized the voices of Indigenous women and their stories, and made space for them to participate in and lead conversations. A team member emphasized frustration and despondency at continual gender mainstreaming, but also hope that alternative discourses were circulating, albeit at the margins of the meeting.

In this way, through creating deliberate, open channels for discussion, the team could pinpoint, but not entirely relieve the tensions around emotional labor stemming from an individual's positionality (for example gender). These tensions emerged within and across the team, in interactions with events and participants. At the same time, because of the rigorous nature of doing FPE and ethnography, particularly over the short-term at global environmental governance events and using compressed "thick" ethnographic practice, the burden can be quite high, especially for team members of color. Even with open channels for discussion, the emotional and affect-laden facets of practice remained generative and volatile, and the team engaged head on with the "bodily memory of fieldwork." We welcomed insights to further address how intrapersonal and interpersonal dynamics, especially on a team with researchers from a variety of intersectional positionalities, unfolded as well as how we could understand these experiences to explore how power was experienced at events. We tried to tackle the issue by engaging in different mentoring strategies (cascade, peer-to-peer) and team configurations so that we could address the power relations within the team, and across team-participant dynamics built from normative 
hierarchies in academia (rank, degree type, etc.). While most team members continued to embrace reflexivity as a key component of the process, their emotional labor required more attention and improvement, especially in navigating power differentials that team members experienced and perceived to be barriers for COP21 or WCC attendees. The tacit, emotional, and other labor described also contributed to a broader understanding of the co-production of knowledge during the ebb and flow of ethnographic practice. Through our adaptations of the CEE model, our work reflected the challenges of putting Tuana's (1996) principles into practice (recognizing the epistemic value of affective processes and examining the role of embodiment in the knowledge process).

\section{Challenge II: Collaboration and co-production}

We also found that practicing CEE across interdisciplinary boundaries facilitated what we call 'theoretical responsibility.' We considered the ethnographic-theoretical dialog as mediated by the ongoing coproduction of knowledge through responsible negotiation and cooperation among team members and participants (Lin et al. 2007: 11). Interdisciplinary CEE was a key challenge to doing ethnography at sites of global environmental governance. As noted above, we sought to address any obstacles by unifying our CEE team in a geographical region, and by using social media. We also identified a clear research activity plan and defined our focal analytics, had a training and mentoring plan in place, and a detailed communication strategy employed processual characteristics for responsible team-based work.

We saw firsthand how and in what way our interdisciplinary trainings on ethnography and feminist political ecology were borne out, and how synergistic tensions emerged, fizzled out, or remained knotty. While all shared a common approach for CEE, we found there was less consensus on the work ethnography can do or how and what way to address power and privilege in the research process. We saw tensions surface, mostly visibly across disciplinary divisions. There were also themes that have emerged elsewhere in critical work, such as the subjective/objective divide (Vrasti 2008, 2010), the question of generating comparative or generalizable work (Wedeen 2010; Yanow 2009: 295), the broad and confusing nature of ethnographic practice for those who had not had much experience with it before (Schatz 2009), settler-scholar logics (Bozhkov et al. 2020), and the lack of training opportunities in ethnography sui generis.

We balanced informal moments of sharing throughout the day, conversations with participants, and formal team briefings. This was important to prioritize collaborative data collection, team debriefings, and individual reflections. Although we had originally planned for team briefings each day at both sites, the logistics of our accommodation and our schedules made this difficult. In Paris, we held subteam briefings (Climate Generations team and Blue Zone team) each day, with full team debriefings approximately every other day. At the WCC, we initially started briefings in the evening but then moved them to the morning. We identified moments that we could skip, and changed our meeting times when necessary to accommodate last minute changes. We built these collaborations through a variety of mechanisms, including the consolidation of the team, and hoped that the spaces of sharing would happen through the cross-disciplinary pairings we set up. Moreover, different types of social media and other forms of communication - face-to-face, email exchanges, text messages, and other spaces became integral to practice.

In these meetings, we planned for and reflected upon events, troubleshot data management issues, and focused on power and privilege across the team and with participants. Nevertheless, team meetings provided an important space to ground experience:

Team meetings. Although, I have to admit team meetings were always hard to go to because they were at the end of the day or very early in the morning ... but the information shared in these meetings was vital for reconnecting the team and broadening ones perspective of the WCC as a whole. For me, the strength of CEE is in the team or group aspect of doing research and sometimes you end up going all day not seeing your team members or anyone you know for that matter. The team meetings perform as an important methodological tool for grounding yourself in the team's goals and your ultimate research questions. (Graduate Team Member, WCC) 
Understanding the analytics and being able to flag certain analytics while at events proved to be one of the most challenging aspects of our research project. However, team debriefs allowed for opportunities to reflect on sessions we had attended and then piece our reflective thoughts together with analytical interpretations. This seemed most helpful during a mentoring breakfast towards the end of the WCC; two of my grad student mentors and I ate breakfast at a local café and while at first the task to describe what analytics we had seen so far seemed daunting, having the ideas of my team members helped me understand the analytical aspects of my own experiences. We could all confirm some of the themes that had been recurring throughout the conference, even as our attendance varied from the Pavilions or various workshops and sessions in the main part of the WCC. (Undergraduate Team Member, WCC)

In these cases, reconnection with the team during the event, and the concurrent and peer-to-peer mentorship structures, seemed to support team members in working through how to apply their experiences to our research design. In similar instances, team members talked about the uniqueness of these spaces of shared responsible action in CEE as being key moments in the team-based ethnographic process:

One of the most valuable aspects of CEE is the ability to converse with your team members and connect to different sessions to ultimately understand different events at the WCC. This can be done in the hallways of the convention center, over dinner, during transport, or even at the bathroom sink. Our team from the WCC was particularly strong at staying in touch with one another by sharing our different experiences and how they link together. One such instance is recorded in my field notes, where [another team member] and I started discussing our contact group sessions, and we recorded it on our phone to later transcribe. I think some of our most important insights appeared during these casual conversations and as the WCC went on we started making a point to record these instances-so that they could add value to our analysis of the WCC. (Graduate Team Member, WCC)

So, team members experienced firsthand the processual challenges and benefits of doing collaborative work. After the events were over, we continued with generating the initial analyses and writing projects together and reached out to others, including Indigenous scholars and leaders, to get feedback on our process and our findings. During writing retreats, team members further commented on the process and demonstrated how their varying experiences and their training had invited them to engage with ethnography and political ecology in a new way. We co-generated ideas during these retreats about scholarship, the type of knowledge products we were co-producing, and how to circulate findings. This helped to reinforce and amplify the CEE experience.

Another tension emerged in the way we addressed responsibility and our commitment to feminist philosophies. We questioned the production of public scholarship and other forms of knowledge "products", a term we found problematic since it suggests ownership and extraction. For example, in Paris a discussion emerged early on as we navigated public scholarship on social media, which we framed as a corpus of knowledge products made in real-time at the event. In one instance, a graduate team member posed a question to us as to whether we should be posting photos of recognizable individuals. This form of witnessing, this team member urged, was critical to activist scholarship and one of the fundamental tenets of registering responses that might otherwise be invisible; priorities which we had discussed as a team. The team member, who identified as an activist scholar, argued that this practice also would still be in alignment with the rules associated with recording at UNFCCC sessions, where photographs were permitted in public areas and meeting rooms. Others disagreed with placing photographs of individuals on our public twitter site. This raised several ethical questions among the team members. We were uncomfortable with "giving voice" to individuals in ways that may not have been desired. Our team members had different experiences with media as a form of public scholarship, and we needed to remember that the internet is a surveilled space, with the possibility of symbolic misrepresentation or even violence. The faculty and the graduate students though differently about this, and there were tensions. Ultimately, we choose to flag the discussion as one for ongoing debate, but for our approach 
at COP21, we left the photographing of people to the other media activists and archivists at the event and we made sure our tweets, if they included photos, did not call attention to identifiable individuals.

In another example, one team member placed heightened emphasis on how she engaged with Indigenous and non-Indigenous participants during a WCC Knowledge Café event focused on multicultural education in Hawai'i, especially among young people. With several Indigenous Peoples in the small group present at the discussion table, she chose to be an active listener and found that this pushed her to listen more deeply with the other participants. Whether she was learning about the struggles of Indigenous land rights in Laos or having lunch with an Indigenous woman after the session, this proved to important for decentering epistemic authority and questioning how and in what way to engage in meaningful research.

She talked about the team research with her lunch partner, and heard her reflections on allyship, as an Indigenous woman. The lunch conversation focused on how non-Indigenous people can be allies for Indigenous Peoples and rights instead of silencing them in global environmental governance space like the WCC. This participant found that the Knowledge Café discussions and ones like it were important but insufficient, and wanted the WCC to officially support Indigenous leaders and their struggles. Yet, at the same time, for the researcher the experience also resurfaced difficult questions about the project: what was her role in this space as an ally? What were her obligations as a feminist CEE researcher to actively listen, dialogue, or engage? How and in what way should this be represented in public engagement forums of work? How could she move this beyond the standard political ecology principles of practice to reflect feminist work?

In addition to the tensions around allyship and public scholarship that surfaced while doing feminist political ecology research, a final issue experienced by our team was a failure to see the writing and analytical process as part of a collaborative ethnographic process that also intersected with feminist methodologies. While we found the training modules effective in helping team members from different disciplines engage in feminist research designs, more work was needed to help see the necessity of collaboration after data collection, not only within the team but with other scholars and interlocutors. Several team members saw the writing retreats as an important space for knowledge co-production, but not as part of doing responsible team-based ethnography or feminist political ecology. As Mauthner and Doucet (2008: 974) highlight: "Bourdieu also argues that 'the construction of the object' is 'no doubt the most crucial research operation and yet the most completely ignored, especially by the dominant tradition, organized as it is around the opposition between 'theory' and 'methodology' (Bourdieu and Wacquant 1992: 224; see also Stanley 1990: 12)." How work is analyzed and then co-written ethnographically with a critical and feminist lens, was less visible and tangible to team members. Writing retreats were sites in which translational moments were debated and discussed, but were sometimes seen as less important than the "collecting data" portion of the work. In fact, constantly questioning why we are doing this work, to what end, within what intersubjective experiences, and with whom, needs to constantly pulse through the project.

\section{Conclusion}

We have argued for a better integration of feminist methodologies with feminist political ecology, particularly in team-based settings. As team-based and interdisciplinary research continues to thrive as one of the new norms of doing environmental science, feminist political ecologists should continue to consider power dynamics not only theoretically and empirically, but also methodologically. This should include consideration of the formation of research teams, collaboration, relations with research participants and the institutional contexts in which work is practiced (Mauthner and Doucet 2008). Specifically, our studies of two events show the potential for using CEE to carry out the commitments of feminist political ecology methodologically, in key politicalized global spaces.

We suggested that CEE offers many possibilities to reassess research designs, and to offer new insights on how to conduct feminist team-based ethnographically-oriented political ecology in short-term but intensive, high-stakes spaces. In Table 3, we propose questions to guide teams interested in doing feminist political ecological work. These questions emerged out of the tensions and generative possibilities of how our team integrated Tuana's three principles of practice (1996), reflecting the broader political commitments of feminist philosophies in our work. These principles included adopting a dynamic approach to knowledge holders, 
recognizing epistemic forms of power, and in doing so prioritizing affective processes and embodied ways of knowing. Ultimately, we sought to generate a relational practice that attended to longstanding feminist commitments to social relations, labors, positionalities, and sources of knowledge. We investigated how 'power within teams' impacts power dynamics, and how power relationships shape teams, the research process, and observations of power.

\begin{tabular}{|c|c|}
\hline $\begin{array}{l}\text { Research design and } \\
\text { methodology }\end{array}$ & A Feminist Political Ecology approach \\
\hline Research questions & $\begin{array}{l}\text { - } \quad \text { How and in what way did the research question emerge? } \\
\text { - Does the research questions engage feminist, political ecology, and/or feminist } \\
\text { political ecology questions? }\end{array}$ \\
\hline $\begin{array}{l}\text { Ontologies and } \\
\text { epistemologies }\end{array}$ & $\begin{array}{l}\text { - What are the assumptions, philosophies, and paradigms guiding the research? } \\
\text { - What are the principles and protocols guiding this work? } \\
\text { - What are the types of knowledge and knowledge holders recognized in research? } \\
\text { - How and in what way is knowledge produced? (e.g. jointly, collaboratively, } \\
\text { cooperatively...?) } \\
\text { theoretically, methodologically, and institutionally? } \\
\text { Does the project acknowledge settler colonial histories and address these in practice } \\
\text { both within the team and at home institutions of higher education? }\end{array}$ \\
\hline Case selection & $\begin{array}{l}\text { - Where will the research take place, and with whom? } \\
\text { - } \quad \text { How and in what way will criteria be generated to make final decisions about } \\
\text { research? } \\
\text { Are multiple and plural scales represented (e.g. geographical, temporal, embodied, } \\
\text { affective, digital, multimodal, etc.)? }\end{array}$ \\
\hline $\begin{array}{l}\text { Team composition } \\
\text { and flow }\end{array}$ & $\begin{array}{l}\text { - Who will work together and 'who decides'? } \\
\text { - } \quad \text { Will there be attention to peoples with different intersectional identities? } \\
\text { - } \quad \text { Will there be attention to whiteness, race, and racialization (Mollet and Faria 2013)? } \\
\text { - What will be the strategies to address team trust and affective labor? }\end{array}$ \\
\hline $\begin{array}{l}\text { Team building and } \\
\text { mentoring }\end{array}$ & $\begin{array}{l}\text { - What form of mentoring is built into the team? } \\
\text { - How and in what way will the team communicate? Will it be an inclusive approach? } \\
\text { - Will there be a priority placed on multiple different types of interactions? } \\
\text { - Will there be established and shared team protocols and research goals? } \\
\text { How will different types of academic work be recognized, including care work and } \\
\text { emotional labor, in all phases of the research process? }\end{array}$ \\
\hline Sampling & $\begin{array}{l}\text { - What are the assumptions, philosophies, and paradigms guiding 'sampling'? } \\
\text { - } \quad \text { How can sampling be responsible, respectful, and relational? }\end{array}$ \\
\hline Methods & $\begin{array}{l}\text { - What are the assumptions, philosophies, and paradigms guiding 'data collection'? } \\
\text { - } \quad \text { Do the methods align with methodological commitments and theories? } \\
\text { - } \quad \text { Are public-facing, activist, or advocacy-based methods used? }\end{array}$ \\
\hline Analysis & $\begin{array}{l}\text { - What are the assumptions, philosophies, and paradigms guiding 'data analysis'? } \\
\text { - } \quad \text { "How do we communicate the limits of our categories in the final representation?" } \\
\text { (D'Iganzio and Klein 2016: np) } \\
\text { - Will there be checking and/or iterative feedback from participants, interlocutors, and } \\
\text { knowledge co-producers? } \\
\text { - What types of 'data' is not represented or visible? }\end{array}$ \\
\hline
\end{tabular}




\begin{tabular}{|l|ll|}
\hline Knowledge sharing & $\bullet \begin{array}{l}\text { How will team members and co-producers be recognized in different forms of } \\
\text { knowledge communication? }\end{array}$ \\
$\qquad \begin{array}{l}\text { What are the forms of knowledge communication, and to whom and how will they be } \\
\text { circulated? }\end{array}$ \\
$\begin{array}{l}\text { What are the ways in which this process might marginalize, make absent, or further } \\
\text { produce injustices and invisibilities? }\end{array}$ \\
How and in what way will project metadata be organized, curated, stored, and shared?
\end{tabular}

Table 3: Feminist Political Ecology design questions. Source: Authors.

The combined approach of collaborative event, digital, and visual ethnography that emphasized public scholarship and diverse ways of knowing attend to and respond in many ways to feminist commitments. Our engagement with social media to advance real-time scholarship provides another form of relational ways of participating in or witnessed the doing of the work of global environmental governance. Nevertheless, these public forms of scholarship were also sites of tension as we considered how such digital spaces intersect with symbolic forms of violence, activist scholarship, and the slippery slope of speaking for or with. Similarly, the emotional labor of doing field work in high stakes spaces was a key point of tension. To this end, in order to demonstrate our prioritization of reflexivity we made overt our inclusion of care work and affective labor, documented through fieldnotes but also processed through embodiment and dialogical moments during CEE.

In doing so, we made two shifts, first in reconceptualizing who has the power to create and perform knowledge and second in the form of collaborative scholarship. The selection, mentorship, and ultimate composition and conceptualization of our team and how our team engaged with participants responded to feminist political ecologists' longstanding interest in inter- and interpersonal scales and feminist philosophies in disrupting normative notions of knowledge holders. We explicitly confronted epistemological tensions through our team constitution, especially related to activist scholarship as well as affective tensions. In order to build our feminist team, we prioritized face-to-face interactions across all phases of the project (trainings, meetings, writing retreats) and interdisciplinarity and allyship. The density and intensity of data collection for CEE - especially in a team environment - makes it all more important to create pathways that emphasize feminist approaches in which team members can rely on to attend to their own positionalities, meaningfully gain tacit knowledge, address power and privilege, and attend to the success of the research project. Moreover, many team members felt the importance of both the team-based work they were doing and intangible experiences that they were having as important spaces for the collaborative knowledge production process.

We found that attention to processual aspects of the data collection was a key factor of doing feminist work; it provided an important space for addressing notions of responsibility and offered possibilities for examining power within the academy as well as individually. However, improvement is needed on interweaving feminist political ecology practice throughout the research life cycle. Still, after both CEE events, all team members had an enhanced understanding of what doing feminist political ecology and ethnography is, despite challenges, tensions, and some shortcomings. We achieved this through mentorship and training from the inception to the write-up of project data. In all of these phases, there was careful attention to ontologies and epistemologies, affective labor, workflow, communication channels, and responsibilities of team members. This type of training provided important immersive experiences to engage with it in practice. However, most team members failed to see writing as part of the collaborative process, which is a key area for future improvement of CEE. We faced specific hurdles based on where team members were in their academic careers and in our team structure and composition. For example, while most of the student team members had some experience with research, many had not yet seen a research project all the way through, thus may not have understood the complex dynamics of research methodologies unfolding at all stages of the process.

While we worked to unsettle epistemic normativity and settler colonialism, we also acknowledge that our team design and the way we carried out our work, while perhaps challenging translational power, did not disrupt institutional power. For example, whereas we were attentive how our own positionalities impacted what and how we "see" and recognized are part of ongoing legacies of power-laden researcher-researched relationships; the absence of Indigenous researchers in our teams were key weaknesses that needed additional work not only in terms of research methodologies but also work required for transformation in the academy (see Tuhiwai Smith 2013). It was not enough that our attention to power drew attention to hierarchical 
differences of power within the research team based on our positionality. Nor was it enough that our work highlighted how participants and organizations disrupted or reinforced mainstream approaches to discursive and material power embedded in the institutional conditions that shaped sites of global environmental governance and how these acts sought to influence Indigenous Peoples' and Local Communities' agendas across these sites. Future methodological work in CEE is needed to decolonize the practice.

Nevertheless, by engaging in a relational form of ethnography through our adapted and interdisciplinary CEE methodology, we show how the recognition of diverse and plural epistemologies are foundational preconditions to integrating feminist principles in feminist political ecology research (see Schlosberg 2004 : 219 for this in an environmental justice context; Moon and Blackman 2014; Sultana 2020). This methodology allowed us to recognize and respect situated knowledges, not simply within the substantive portions of research but also in the research design and the methodologies which are critical to disrupting knowledge hegemonies and provide different modes of practicing feminist political ecologies. As Zanotti et al. (2019) notes, multiple strategies have been employed to reach the goals of socially just, politically conscious, and equitable research. We hope that this article demonstrates ways in which research teams should be attentive to labor in designing a feminist political ecology team, and to recognizing power and privilege in praxis. Moreover, we recognize more work is needed in feminist political ecology - not only to address power, but specifically to attend to settler-scholar logics (Dhillon 2020).

\section{References}

Ackerly, B.A. 2000. Political theory and feminist social criticism. Cambridge: Cambridge University Press.

Ahlborg, H. and A.J. Nightingale. 2018. Theorizing power in political ecology: the 'where' of power in resource governance projects. Journal of Political Ecology 25(1): 381-401.

Alcoff, L. and E. Potter. 1993. Feminist epistemologies. London: Routledge.

Bäckstrand, K. 2006. Democratizing global environmental governance? Stakeholder democracy after the World Summit on Sustainable Development. European Journal of International Relations 12(4): 467-498. doi:10.1177/1354066106069321

Bain, A.L. and W.J. Payne. 2016. Queer de-participation: reframing the co-production of scholarly knowledge. Qualitative Research 16(3): 330-340.

Bonilla, Y. and J. Rosa. 2015. \# Ferguson: digital protest, hashtag ethnography, and the racial politics of social media in the United States. American Ethnologist 42(1): 4-17.

Bordo, S.R. and A.M. Jaggar (eds.) 1989. Gender/Body/Knowledge: feminist reconstructions of being and knowing. New Brunswick, NJ: Rutgers University Press.

Bozhkov, E., C. Walker, V. McCourt and H. Castleden. 2020. Are the natural sciences ready for truth, healing, and reconciliation with Indigenous Peoples in Canada? Exploring 'settler readiness' at a world-class freshwater research station. Journal of Environmental Studies and Sciences 10: 226-241.

Brosius, J.P. 2004. Indigenous peoples and protected areas at the World Parks Congress. Conservation Biology 18(3): 609-612.

Brosius, J.P. and L.M. Campbell. 2010. Collaborative Event Ethnography: conservation and development tradeoffs at the Fourth World Conservation Congress. Conservation and Society 8(4): 45-255.

Bulkeley, H. 2005. Reconfiguring environmental governance: towards a politics of scales and networks. Political Geography 24(8): 875-902.

Callon, M. 1984. Some elements of a sociology of translation: domestication of the scallops and the fishermen of St Brieuc Bay. The Sociological Review 32(1): 196-233.

Campbell, L.M., C. Corson, N.J. Gray, K.I. MacDonald and J.P. Brosius. 2014. Studying global environmental meetings to understand global environmental governance: collaborative event ethnography at the Tenth Conference of the Parties to the Convention on Biological Diversity. Global Environmental Politics 14(3): 1-20.

Caretta, M.A. and Y. Riaño. 2016. Feminist participatory methodologies in geography: creating spaces of inclusion. Qualitative Research 16(3): 258-266. 
Coleman, E.G. 2010. Ethnographic approaches to digital media. Annual Review of Anthropology 39: $487-505$.

Corson, C., L.M. Campbell and K.I. MacDonald. 2014. Capturing the personal in politics: ethnographies of global environmental governance. Global Environmental Politics 14(3): 21-40.

Corson, C., L.M. Campbell, P. Wilshusen and N.J. Gray. 2019. Assembling global conservation governance. Geoforum 103: 56-65.

D'Ignazio, C. and L.F. Klein. 2016. Feminist data visualization. In Workshop on Visualization for the Digital Humanities (VIS4DH), Baltimore. IEEE. Accessed at: http://www.kanarinka.com/wpcontent/uploads/2015/07/IEEE_Feminist_Data_Visualization.pdf

Dhillon, J. 2018. The future of anthropology starts from within. Hot Spots, Cultural Anthropology website, September 26, 2018. https://culanth.org/fieldsights/1532-the-future-of-anthropology-starts-from-within

Dhillon, C.M. 2020. Indigenous feminisms: disturbing colonialism in environmental science partnerships. Society of Race and Ethnicity https://doi.org/10.1177/2332649220908608

Djenontin, I.N.S. and A.M. Meadow. 2018. The art of co-production of knowledge in environmental sciences and management: lessons from international practice. Environmental Management 61(6): 885-903.

Doolittle, A.A. 2010. The politics of Indigeneity: Indigenous strategies for inclusion in climate change negotiations. Conservation and Society 8(4): 286-291.

Elliott, L. 1998. The global politics of the environment. London: Macmillan.

Elmhirst, R. 2011. Introducing new feminist political ecologies. Geoforum 42(2): 129-132.

Ensher, E.A., C. Thomas and S.E. Murphy. 2001. Comparison of traditional, step-ahead, and peer mentoring on protégés' support, satisfaction, and perceptions of career success: a social exchange perspective. Journal of Business and Psychology 15: 419-438.

González-Hidalgo, M. and C. Zografos. 2020. Emotions, power, and environmental conflict: expanding the 'emotional turn' in political ecology. Progress in Human Geography 44(2): 235-255.

Gray, N.J., C. Corson, L.M. Campbell, P.R. Wilshusen, R.L. Gruby and S. Hagerman. 2020. Doing strong collaborative fieldwork in human geography. Geographical Review 110(1-2): 117-132.

Hall, K.L., A.X. Feng, R.P. Moser, D. Stokols and B.K. Taylor. 2008. Moving the science of team science forward: collaboration and creativity. American Journal of Preventive Medicine 35(2): S243-S249.

Haraway, D. 1988. Situated knowledges: the science question in feminism and the privilege of partial perspective. Feminist Studies 14(3): 575-599.

Harcourt, W. and I.L. Nelson (eds.). 2015. Practising feminist political ecologies: moving beyond the 'green economy'. London: Zed.

Harding, S. 1991. Whose science, whose knowledge? Thinking from women's lives. Milton Keynes: Open University Press.

Harrison, F.V. 1991. Decolonizing anthropology: moving further toward an anthropology for liberation. Washington DC: American Anthropological Association.

Hawkins R., D. Ojeda, K. Asher, B. Baptiste, L. Harris, S. Mollett, A.J. Nightingale, D. Rocheleau, J. Seager and F. Sultana. 2011. A discussion. Gender and environment: critical tradition and new challenges. Environment and Planning D: Society and Space 29(2): 237-253.

Hesse-Biber, S.N. (ed.). 2011. Handbook of feminist research: theory and praxis. Thousand Oaks, CA: Sage.

Howitt, R. and S. Jackson. 1998. Some things do change: Indigenous rights, geographers and geography in Australia. The Australian Geographer 29(2): 155-173.

Jaggar, A.M. (ed.). 2015. Just methods: an interdisciplinary feminist reader. London: Routledge.

Jarosz, L. 2004. Political ecology as ethical practice. Political Geography 23(7): 917-927.

Jarzabkowski, P., R. Bednarek and L. Cabantous. 2015. Conducting global team-based ethnography: methodological challenges and practical methods. Human Relations 68(1): 3-33.

Jasanoff, S. 1996. Beyond epistemology: relativism and engagement in the politics of science. Social Studies of Science 26(2): 393-418. 
Johnson, J.C., C. Avenarius and J. Weatherford. 2006. The active participant-observer: applying social role analysis to participant observation. Field Methods 18(2): 111-134.

Kuyper, J., K. Bäckstrand, and H. Schroeder, H. 2017. Institutional accountability of nonstate actors in the UNFCCC: exit, voice, and loyalty. Review of Policy Research 34(1): 88-109.

Lamb, V. 2018. Who knows the river? Gender, expertise, and the politics of local ecological knowledge production of the Salween River, Thai-Myanmar border. Gender, Place and Culture 25(12): 1703-1718.

Lassiter, L.E. 2005. Collaborative ethnography and public anthropology. Current Anthropology 46(1): 83-106.

Law, J. and V. Singleton. 2014. ANT, multiplicity and policy. Critical Policy Studies 8(4): 379-396.

Leavy, P. and A. Harris. 2018. Contemporary feminist research from theory to practice. New York: Guilford Press.

Lin, Y.W., R. Procter, P. Halfpenny, A. Voss and K. Baird. 2007. An action-oriented ethnography of interdisciplinary social scientific work. Proceedings. Ann Arbor: Third International Conference on eSocial Science.

MacDonald, K.I. 2010. Business, biodiversity and new 'fields' of conservation: the World Conservation Congress and the renegotiation of organisational order. Conservation and Society 8(4): 256-275.

MacKay, J. and J. Levin. 2015. Hanging out in international politics: two kinds of explanatory political ethnography for IR. International Studies Review 17(2): 163-188.

Margaret Fonow, M. and J.A. Cook. 2005. Feminist methodology: new applications in the academy and public policy. Signs: Journal of Women in Culture and Society 30(4): 2211-2236.

Marion Suiseeya, K.R. 2014. Negotiating the Nagoya Protocol: indigenous demands for justice. Global Environmental Politics 14(3): 102-124.

Marion Suiseeya, K.R. and L. Zanotti. 2019. Making influence visible: innovating ethnography at the Paris Climate Summit. Global Environmental Politics 19(2): 38-60.

Massé, F., H. Dickinson, J. Margulies, L. Joanny, T. Lappe-Osthege and R. Duffy. 2020. Conservation and crime convergence? Situating the 2018 London Illegal Wildlife Trade Conference. Journal of Political Ecology 27(1): 23-42.

Mauthner, N.S. and A. Doucet. 2008. 'Knowledge once divided can be hard to put together again': an epistemological critique of collaborative and team-based research practices. Sociology 42(5): 971-985.

Mehta, L. 2016. Dianne Rocheleau: the feminist political ecology legacy and beyond. In Harcourt, W. (ed.). The Palgrave handbook of gender and development. London: Palgrave Macmillan. Pp. 262-275.

Mollett, S. and C. Faria. 2013. Messing with gender in feminist political ecology. Geoforum 45: 116-125.

Mollett, S. and C. Faria. 2018. The spatialities of intersectional thinking: fashioning feminist geographic futures. Gender, Place and Culture 25(4): 565-577.

Moon, K. and D. Blackman. 2014. A guide to understanding social science research for natural scientists. Conservation Biology 28(5): 1167-1177.

Moon, K., T.D. Brewer, S.R. Januchowski-Hartley, V.M. Adams and D.A. Blackman. 2016. A guideline to improve qualitative social science publishing in ecology and conservation journals. Ecology and Society 21(3).

Nightingale, A.J. 2011. Bounding difference: intersectionality and the material production of gender, caste, class and environment in Nepal. Geoforum 42(2): 153-162.

Nightingale, A.J. and K.N. Rankin. 2014. Political transformations: collaborative feminist scholarship in Nepal. Himalaya 34(1):105-117.

Nyantakyi-Frimpong, H. 2019. Combining feminist political ecology and participatory diagramming to study climate information service delivery and knowledge flows among smallholder farmers in northern Ghana. Applied Geography 112. https://doi.org/10.1016/j.apgeog.2019.102079

O'Neill, K. 2017. The environment and international relations. Cambridge: Cambridge University Press. 
O'Rourke, M. and S.J. Crowley. 2013. Philosophical intervention and cross-disciplinary science: the story of the Toolbox Project. Synthese 190(11): 1937-1954.

Oksala, J. 2016. Affective labor and feminist politics. Signs: Journal of Women in Culture and Society 41(2): 281-303.

Ortner, S.B. 2005. Subjectivity and cultural critique. Anthropological Theory 5(1): 31-52.

Packard, B.W. 2003. Student training promotes mentoring awareness and action. Career Development Quarterly 51(4): 335-345.

Pink, S. 2006. The future of visual anthropology: engaging the senses. London: Routledge.

Pink, S. and J. Morgan. 2013. Short-term ethnography: intense routes to knowing. Symbolic Interaction 36(3): 351-361.

Reimerson, E. 2013. Between nature and culture: exploring space for indigenous agency in the Convention on Biological Diversity. Environmental Politics 22(6): 992-1009.

Robbins, P. 2012. Political ecology: a critical introduction. Oxford: Blackwell.

Rocheleau, D.E. 1995. Maps, numbers, text, and context: mixing methods in feminist political ecology. The Professional Geographer 47(4): 458-466.

Rocheleau, D.E. 2008. Political ecology in the key of policy: from chains of explanation to webs of relation. Geoforum 39(2): 716-727.

Rocheleau, D.E., B. Thomas-Slayter and E. Wangari (eds.). 1996. Feminist political ecology: global issues and local experiences. London: Routledge.

Rodó-de-Zárate, M. and M. Baylina. 2018. Intersectionality in feminist geographies. Gender, Place and Culture 25(4): 547-553.

Schatz, E. 2009. What kind(s) of ethnography does political science need? In Schatz, E. (ed.). Political ethnography: what immersion contributes to the study of power. Chicago: University of Chicago Press. Pp. 303-318.

Schlosberg, D. 2004. Reconceiving environmental justice: global movements and political theories. Environmental Politics 13(3): 517-540.

Shayne, J. (ed.). 2014. Taking risks: feminist activism and research in the Americas. New York: SUNY Press.

Sultana, F. 2020. Political ecology 1: from margins to center. Progress in Human Geography https://doi.org/10.1177/0309132520936751

Sundberg, J. 2003. Masculinist epistemologies and the politics of fieldwork in Latin Americanist geography. The Professional Geographer 55(2): 180-190.

Tengö, M., R. Hill, P. Malmer, C.M. Raymond, M. Spierenburg, F. Danielsen, T. Elmqvist and C. Folke. 2017. Weaving knowledge systems in IPBES, CBD and beyond-lessons learned for sustainability. Current Opinion in Environmental Sustainability 26: 17-25.

Thomas, D.A. 2018. Decolonizing disciplines. American Anthropologist 120(3): 393-397.

Todd, Z. 2016. An Indigenous feminist's take on the ontological turn: 'ontology' is just another word for colonialism. Journal of Historical Sociology 29(1): 4-22.

Tracy, S.J. 2010. Qualitative quality: eight "big-tent" criteria for excellent qualitative research. Qualitative Inquiry 16(10): 837-851.

Tuana, N. 1996. Revaluing science: starting from the practices of women. In L. Hankinson Nelson and J. Nelson (eds.). Feminism, science, and the philosophy of science. Dordrecht: Springer. Pp. 17-35.

Tuhiwai-Smith, L. 2013. Decolonizing methodologies: research and Indigenous peoples. London: Zed.

[UNDRIP] United Nations. 2007. United Nations Declaration on the Rights of Indigenous Peoples. Retrieved from http://www.un.org/esa/socdev/unpfii/documents/DRIPS_en.pdf

Velasquez Runk, J. 2014. Enriching indigenous knowledge scholarship via collaborative methodologies: beyond the high tide's few hours. Ecology and Society 19(4).

Vrasti, W. 2008. The strange case of ethnography and International Relations. Millennium 37(2): 279-301. 
Vrasti, W. 2010. Dr. Strangelove, or how I learned to stop worrying about methodology and love writing. Millennium 39(1): 9-88.

Wallbott, L. 2014. Indigenous peoples in UN REDD+ negotiations: "importing power" and lobbying for rights through discursive interplay management. Ecology and Society 19(1): 21.

Wedeen, L. 2010. Reflections on ethnographic work in Political Science. Annual Review of Political Science 13: 255-272.

West, P. 2018. From reciprocity to relationality: anthropological possibilities. Hot Spots, Cultural Anthropology website, September 26, 2018. https://culanth.org/fieldsights/1525-from-reciprocity-torelationality-anthropological-possibilities

Witter, R., K.R. Marion Suiseeya, R.L. Gruby, S. Hitchner, E.M. Maclin, M. Bourque and J.P. Brosius. 2015. Moments of influence in global environmental governance. Environmental Politics 24(6): 894-912.

Yanow, Dvora. 2009. Dear Author, Dear Reader: the third hermeneutic in writing and reviewing ethnography. In Edward Schatz (ed.) Political ethnography: what immersion contributes to the study of power. Chicago: University of Chicago Press. Pp. 275-302.

Zanotti, L., C. Carothers, C. Apok, S. Huang, J. Coleman and C. Ambrozek. 2020. Political ecology and decolonial research: co-production with the Iñupiat in Utqiagivik. Journal of Political Ecology 27: 4366. 